\title{
Review
}

Neonatology

\section{The Molecular Era of Surfactant Biology}

\author{
Jeffrey A. Whitsett \\ Perinatal Institute, Section of Neonatology, Perinatal and Pulmonary Biology, Cincinnati Children's Hospital Medical \\ Center, and the University of Cincinnati College of Medicine, Cincinnati, Ohio, USA
}

\section{Key Words}

Lung diseases · Alveolar homeostasis · Surfactant biology

\begin{abstract}
Advances in the physiology, biochemistry, molecular and cell biology of the pulmonary surfactant system transformed the clinical care and outcome of preterm infants with respiratory distress syndrome. The molecular era of surfactant biology provided genetic insights into the pathogenesis of pulmonary disorders, previously termed 'idiopathic', that affect newborn infants, children and adults. Knowledge related to the structure and function of the surfactant proteins and their roles in alveolar homeostasis has provided new diagnostic, prognostic and therapeutic tools to advance our understanding of the causes and treatments of acute and chronic lung diseases. Severe lung disease in newborn infants and older patients is caused by mutations in genes regulating alveolar epithelial cells and surfactant homeostasis. Mutations in genes encoding the surfactant proteins, transcription factors critical for alveolar morphogenesis and surfactant clearance, are now known to play important roles in the pathogenesis of chronic lung diseases. Identification of the genes underlying the diseases of alveolar homeostasis is useful for the diagnosis of lung disease before and after birth.

(c) 2014 S. Karger AG, Basel
\end{abstract}

\section{Introduction}

Rapid advances in physiology and biochemistry made in the mid-20th century provided insights into the mechanisms underlying the previously perplexing problem of respiratory distress syndrome (RDS) in preterm infants. Before 1970, RDS was a common, often lethal, pulmonary disorder causing respiratory failure in preterm newborn infants, regardless of the degree of prematurity. Analysis of lung tissues from preterm infants that had died from RDS revealed a paucity of surface-active lipid-rich material needed to reduce surface tension at the air-liquid interface [1]. The ability to measure alveolar blood gases, adjust oxygenation and ventilation with continuous positive airway pressure and the technique of mechanical ventilation brought rapid improvements in the morbidity and mortality associated with RDS in preterm infants in the 1970s. The knowledge that pulmonary surfactant is rich in phosphatidylcholine, particularly disaturated palmitoyl phosphatidylcholine, provided the impetus to understanding its biochemistry and structure. Physiologic studies of animal models of RDS demonstrated the efficacy of replacing pulmonary surfactant by means of the intratracheal delivery of surfactant and surfactant lipid extracts in reversing atelectasis and the pathological changes in pulmonary physiology [2]. Organic solvent

\section{KARGER}

E-Mail karger@karger.com

www.karger.com/neo
(C) 2014 S. Karger AG, Basel

$1661-7800 / 14 / 1054-0337 \$ 39.50 / 0$
Jeffrey A. Whitsett, MD

Division of Pulmonary Biology, MLC7029

Cincinnati Children's Hospital Medical Center

Cincinnati, OH 45229-3039 (USA)

E-Mail jeff.whitsett@cchmc.org 
Table 1. Diseases of alveolar homeostasis

\begin{tabular}{llll}
\hline & $\begin{array}{l}\text { Neonatal } \\
\text { respiratory failure }\end{array}$ & $\begin{array}{l}\text { Chronic lung } \\
\text { diseases in } \\
\text { children }\end{array}$ & $\begin{array}{l}\text { Adult } \\
\text { pulmonary } \\
\text { disease }\end{array}$ \\
\hline Genes & SFTPB & SFTPC & SFTPC \\
& ABCA3 & NKX2-1 & SFTPA \\
& SFTPC & CSF-R $1 / 2$ & TEL, TELC \\
& NKX2-1 (TTF-1) & & SLC34ac \\
& FOXM1 & & \\
\hline
\end{tabular}

extracts of bovine and porcine surfactant material were developed that are widely used for the prevention and treatment of RDS in preterm infants [3-5]. These discoveries transformed the care of preterm infants, reducing the morbidity and mortality associated with RDS [6]. The organic solvent extracts of pulmonary surfactant spread rapidly and are stable during repeated dynamic compression of lipid films. The biophysical behaviors of surfactant lipid-rich extracts are highly distinct from those of synthetic phosphatidylcholine-lipid mixtures, indicating that minor components in the organic solvent extracts contribute importantly to the unique surface activity of pulmonary surfactants. Such observations led our laboratory and others to identify two novel surfactant proteins, now-termed SP-B and SP-C, which are critical components of surfactant replacement preparations $[7,8]$. The small, hydrophobic peptides, SP-B and SP-C, were found to impart surfactant-like properties to purified phospholipid mixtures needed for the reversal of atelectasis in surfactant-deficient lungs [8-10]. Concomitant with the advances in the clinical application of surfactant replacement in the 1980s were rapid advances in molecular biology that enabled their purification, the identification of their amino acid sequences and the preparation of antibodies and molecular probes used to clone the cDNAs and genes encoding surfactant proteins $\mathrm{A}, \mathrm{B}, \mathrm{C}$ and $\mathrm{D}$ [11-15 for review] to identify their functions. These molecular tools opened the investigative doors to beginning to understand fundamental questions regarding lung formation, perinatal lung maturation, the structure and function of the surfactant proteins that have been cornerstones for the application of molecular biology in the study of lung biology and the diagnosis and treatment of pulmonary diseases. This new tool-kit was used to (1) quantitate surfactant proteins in pulmonary tissues, bronchoalveolar lavage fluid and serum, (2) identify disease-associated mutations in the genes encoding both the surfactant proteins and those critical for the synthesis of surfactant that provided insight into the molecular basis of 'idiopathic' respiratory failure in full-term infants and other interstitial lung diseases (ILDs) affecting newborn infants and older individuals [16] and (3) produce recombinant surfactant proteins and peptides for the production of synthetic surfactants. This brief review will focus on some of the advances in the application of molecular biology to the pathogenesis, diagnosis and treatment of pulmonary diseases (table 1).

\section{Mutations in Genes Encoding 'Surfactant-Associated' Proteins Cause Respiratory Failure and Chronic Pulmonary Disease}

Mutations in the genes encoding surfactant proteins play a central role in the pathogenesis of respiratory failure in full-term, newborn infants whose clinical courses are unresponsive to intensive care therapies. An ever-enlarging catalogue of mutations and alleles in genes critical for lung formation and function is associated with respiratory disease in infants and older patients $[17,18$ for review]. Sequencing of surfactant-related proteins and thyroid transcription factor-1 (TTF-1) genes provided the diagnostic tools to identify lung disease causing alleles and those contributing to disease susceptibility. Genetic causes of respiratory failure are now routinely considered when term infants present with severe, unexplained respiratory failure with signs and symptoms of RDS that are normally associated with lung disease in preterm infants. These infants usually require oxygen, mechanical ventilation and with continued respiratory failure, are often treated with extracorporeal membrane oxygenation but fail to respond to therapy. $S F T P B$, encoding the surfactant peptide SP-B, a small, amphipathic peptide synthesized by type II alveolar epithelial cells [11, 12], was the first gene associated with this disorder [19]. SP-B is present in animal-based surfactant preparations and when added to phospholipids, enhances their surface properties. SP-B is processed from a precursor protein, proSP-B, which is proteolytically processed by several proteases including napsin, pepsinogen and cathepsins as it transits to lamellar bodies in type II epithelial cells in the alveoli. Studies in transgenic mice lacking SP-B demonstrated that it is required for the formation of lamellar bodies, tubular myelin and surface tension lowering in the peripheral lung, resulting in respiratory failure at birth [20]; likewise, the loss of SP-B in the adult mouse causes respiratory failure [21]. Lack of SP-B disrupts the formation of the lamellar 
body, blocks the normal processing of proSP-C and impairs surfactant reuptake, causing respiratory failure. A number of mutations have been identified in SFTPB that are inherited as autosomal recessive genes [18, 22]. Heterozygosity for alleles causing nonsynonymous changes in the SFTPB have been associated with an increased risk for RDS in patients with chronic obstructive pulmonary disease. Infants with signs and symptoms similar to SP-B deficiency may instead have a deficiency of another protein, ABCA3 (ATP-Binding Cassette A3) as the cause of respiratory failure $[23,24]$. ABCA3 is a large, transmembrane protein located on the surface of the limiting membranes of lamellar bodies in type II epithelial cells. ABCA3 mediates the transfer of phosphatidylcholine into lamellar bodies. A lack of ABCA3 inhibits surfactant packaging and secretion, causing respiratory failure after birth. ABCA3 is encoded by a relatively large gene and cDNA in which numerous mutations have been identified that cause severe lung disease in newborn infants [24 for review]. Pathological evaluations of tissue from infants with SP-B- and ABCA3-related pulmonary disease are consistent with the pathological descriptions of disorders termed 'chronic pneumonitis of infancy', 'infantile alveolar proteinosis', 'infantile chronic lung disease' or 'nonspecific interstitial lung disease', the pathology often being influenced by the age of the infants and the therapies used to treat them [17].

\section{Mutations in NKX2-1 (Thyroid Transcription Factor-1) Cause Cerebral-Thyroid-Lung Syndrome}

The cloning of the surfactant protein genes SFTPA, $S F T P B, S F T P C$, SFTPD and ABCA3 enabled the identification of the transcription factor TTF-1 (encoded by the NKX2-1 gene, a homeodomain-containing transcription factor) as a critical regulator of their expression in type II epithelial cells in the developing and mature lung [25]. TTF-1 is expressed in the thyroid, lung and forebrain, where it plays diverse roles in their formation and function. Subsequent studies demonstrated that TTF-1 is required for lung morphogenesis, regulating the differentiation and proliferation of epithelial progenitor cells that form the respiratory epithelium [26]. TTF-1 regulates the expression of many genes associated with the differentiation of type II epithelial cells prior to birth, including $A B C A 3$ and the genes encoding the surfactant proteins, its activity being required for respiratory adaptation at birth [27]. Mutations in the NKX2-1 gene were identified in patients with respiratory failure or severe chronic lung

The Molecular Era of Surfactant Biology disease that is variably associated with CNS dysfunction (chorea) and hypothyroidism [28, 29]. NKX2-1-related disease is generally associated with haploinsufficiency or mutations in NKX2-1 that are now amenable to genetic diagnosis. A recent study identified an association of a mutation in NKX2-1 with the pulmonary disorder termed neuroendocrine hyperplasia of infancy [30].

\section{Mutations in FOXF1 Cause Alveolar Capillary Dysplasia}

Alveolar capillary dysplasia (ACD) is a rare cause of respiratory failure in newborn infants [31]. Infants usually present soon after birth with severe pulmonary hypertension, cyanosis and respiratory failure that is refractory to ventilatory support and does not resolve after extracorporeal membrane oxygenation. Histopathological studies demonstrate abnormal alveolar formation, a paucity of alveolar capillaries and, frequently, a misalignment of pulmonary arteries and veins. Haploinsufficiency of Foxm1 in transgenic mice caused respiratory failure at birth, associated with striking abnormalities in the formation of the pulmonary vasculature with features similar to those in infants with ACD [32]. Genetic studies on patients with ACD have identified mutations in the human gene [33]. Mutations in FOXF1 are now recognized as the most common genetic cause of the disorder in newborn infants. Foxf1, expressed in mesenchymal cells in the early embryo, plays an important role in the formation of other organs including the heart and gastrointestinal tract. Infants with ACD and mutations in Foxf1 frequently have malformations of other organs [31]. The diagnosis of ACD can be made by identification of mutations in FOXF1, useful for the prenatal and postnatal diagnosis of this severe respiratory disease. In the postnatal mouse lung, Foxf1 plays a role in the regulation of lung inflammation; this supports its potential role in the pathogenesis of lung disease beyond the newborn period [34].

\section{Mutations in SFTPC and Infantile Chronic Lung Diseases}

While neonatal respiratory distress has been associated with mutations of SFTPC in a small number of infants, patients with SFTPC-related disease usually present after the newborn period in infancy [17, 18 for review]. Like $\mathrm{SP}-\mathrm{B}$, the active SP-C peptide is synthesized, processed and secreted by alveolar type II epithelial cells [35]. SP-C 
is present in lamellar bodies, tubular myelin and animalbased surfactant replacement preparations used clinically. SP-C plays an important role in enhancing the rapid spreading and stability of surfactant lipids in the alveolus. Transgenic Sftp $\mathrm{c}^{-/-}$mice, lacking SP-C, survive postnatally but develop severe ILD after birth and after lung injury caused by viral and bacterial pathogens and endotoxin [36-38]. Consistent with these findings, infants with mutations in SFTPC generally present with chronic ILD that is often exacerbated by viral infection. SFTPC-associated ILD is caused by dominantly inherited mutations that cause misfolding of the 'BRICHOS' domain of proSP-C $[39,40]$. Misfolded proSP-C accumulates intracellularly, causing injury to type II epithelial cells [41] which, in turn, causes lung inflammation and remodeling. In some mutations, misfolded proSP-C induces the endoplasmic-reticulum stress response resulting in cytotoxicity, inflammation, remodeling and fibrosis that is associated with ILD $[41,42]$. SFTPC-related lung disease is variably penetrant [43], being influenced by both environmental and other genetic modifiers. SFTPC gene-related disorders may present early in the neonatal period, during childhood or adulthood, although it is rare as a cause of chronic lung disease in adults $[17,44]$. Findings from patients with mutations in SFTPC were the first to highlight the role of the misfolded protein/endoplasmic reticulum stress response in the pathogenesis of pulmonary fibrosis, 'non-specific interstitial pneumonitis', idiopathic pulmonary fibrosis and other disorders broadly classified as ILD.

\section{SFTPA and Telomerase in the Pathogenesis of ILD in Adults}

Human SP-A is encoded by two SFTPA genes, SFTPA1 and SFTPA2. SP-A is synthesized and secreted by airway epithelial cells where it is required for formation of tubular myelin. SP-A plays diverse roles in the innate immune defenses of the lung $[14,45]$. In contrast to SP-B and ABCA3, $\mathrm{SP}-\mathrm{A}$ is not required for perinatal survival of $S f t p a^{-/-}$mice [46]. Mutations in SFTPA are associated with ILD in adults and with susceptibility to pulmonary adenocarcinoma [47 for review]. SP-A consists of a glycosylated Cterminal lectin domain and an $\mathrm{NH} 2$-terminal collagenous domain that forms trimeric complexes that further oligomerize to form multimers in the airway. SP-A plays a critical role in the structure of surfactant lipid particles, but does not play a major role in the regulation of surfactant pool sizes. SP-A binds to endotoxin and viral, bacterial and fungal pathogens in the lung, enhancing their opso- nization and clearance. Like SFTPC, some mutations in SFTPA cause misfolded protein responses and epithelial cell injury. Recent studies support the concept that mutations in SP-A activate TGF- $\beta$ signaling that may be involved in the pathogenesis of alveolar lung disease and lung cancer $[47,48]$. The concept that recurrent epithelial injury is involved in the pathogenesis of ILD is supported by studies demonstrating that mutations in telomeraseassociated genes (TEL and TELC) are associated with chronic pulmonary disease in adults [49-51 for review].

\section{Molecular Diagnostics for Pulmonary Diseases}

Identification of the genes and molecular pathways regulating surfactant homeostasis in type II epithelial cells provided the reagents for the development of clinical tests with genetics, immunochemistry or immunoassay that are useful for diagnosis and prognosis of acute and chronic lung diseases. Purification of the surfactant proteins from lung tissue or after the expression of recombinant surfactant proteins or the synthesis of surfactant protein peptides enabled the development of useful antibodies for the establishment of immunohistochemistry and immunoassays (ELISAs) that are now widely used for the identification of lung cells for the study of lung development and disease. These markers have served as useful indicators of the course of various pulmonary disorders [52-56]. Serum ELISAs for SP-D and SP-A are useful for the prognosis and treatment of patients with various interstitial lung disorders, including sarcoidosis, idiopathic pulmonary fibrosis and pulmonary alveolar proteinosis (PAP) [57]. Likewise, genetic testing has been useful for the identification of 'disorders of surfactant homeostasis' in the newborn period. The considerable allelic heterogeneity in genes encoding the surfactant proteins has enabled assessment of the risk or susceptibility of various surfactant protein gene alleles to lung disease. The molecular identification of mutations in the surfactant protein genes and TTF-1 are now useful tests for prenatal and postnatal diagnosis and the prognosis of disorders of surfactant homeostasis.

\section{The Role of GM-CSF Signaling in the Pathogenesis of Pulmonary Alveolar Proteinosis}

Studies in granulocyte macrophage colony-stimulating factor (GM-CSF) and GM-CSF receptor-deficient mice identified the important role of GM-CSF signaling 
in the regulation of surfactant protein and lipid clearance from the lung [ 58 for review]. Subsequent clinical studies demonstrated that the common form of PAP in adults was caused by anti-GM-CSF antibodies that block GMCSF signaling in alveolar macrophages [59], which is required for the catabolism of pulmonary surfactant proteins. Recent genetic studies in children with early-onset PAP with clinical features similar to those associated with adult autoimmune PAP, demonstrated the autosomal recessive inheritance of mutations in the GM-CSF receptors, CSF2RB and CSF2RA [60-62]. The identification of the critical role of GM-CSF signaling in the regulation of surfactant catabolism has provided novel assays for the diagnoses of both forms of PAP and has enabled new therapies based on treatment with GM-CSF [63] or the correction of GM-CSF receptor-signaling defects that are being actively studied at present [64-66].

\section{Synthesis of Synthetic Surfactant Proteins and Peptides}

Elucidation of the genes, cDNAs and amino acid sequences of the surfactant proteins has provided information that is useful for the engineering of recombinant or synthetic surfactant proteins and peptides. Peptides modeled from the structures of SP-B and SP-C are now produced and recombined with surfactant-like lipids to produce synthetic surfactant mixtures. Novel peptides have been synthesized that confer excellent surfactant-like properties to lipid mixtures. SP-B- and SP-C-like peptide mimics are being actively studied for the treatment of pulmonary diseases [67-70]. KL4, an amphipathic peptide with features of SP-B, was recently approved for the treat- ment of RDS in the USA [69]. Likewise, mixtures of SPB- and SP-C-like peptides have been tested in animal models where they have been found to be effective in enhancing lung function. Synthetic peptide-lipid mixtures have excellent biophysical properties and may be useful for future therapies for the treatment or prevention of RDS and other lung disorders [71, 72].

\section{Summary}

The molecular era of surfactant biology has provided new insights into alveolar homeostasis useful for the diagnosis, prognosis and therapy of lung disorders previously termed 'idiopathic'. The postgenome era of whole genomic and exomic sequencing will likely uncover mutations causing or contributing to inherited and acquired lung diseases that will provide a conceptual framework for the prevention and treatment of pulmonary diseases in patients of all ages in the future.

\section{Acknowledgements}

This work was funded by grants from the National Institutes of Health: HL108907, HL105433, HL110964 and HL095580. The author wishes to thank Ann Maher for typing the manuscript.

\section{Disclosure Statement}

The research laboratory is supported by the National Institutes of Health and the Cystic Fibrosis Foundation. Cincinnati Children's Hospital Medical Center holds patents related to surfactant protein technology. There is no active support from industry of this laboratory.

\section{References}

$\checkmark 1$ Avery ME, Mead J: Surface properties in relation to atelectasis and hyaline membrane disease. Am J Dis Child 1959;97:517-523.

$>2$ Enhorning G, Robertson B: Lung expansion in the premature rabbit fetus after tracheal deposition of surfactant. Pediatrics 1972;50:5866.

-3 Fujiwara T, Maeta H, Chida S, Morita T, Watabe $\mathrm{Y}$, Abe T: Artificial surfactant therapy in hyaline-membrane disease. Lancet 1980;1: 55-59.

-4 Yu S, Harding PG, Smith N, Possmayer F: Bovine pulmonary surfactant: chemical composition and physical properties. Lipids 1983;18: 522-529.
-5 Egberts J, de Winter JP, Sedin G, de Kleine MJ, Broberger U, van Bel F, Curstedt T, Robertson $\mathrm{B}$ : Comparison of prophylaxis and rescue treatment with Curosurf in neonates less than 30 weeks' gestation: a randomized trial. Pediatrics 1993;92:768-774.

6 6 Stevens TP, Harrington EW, Blennow M, Soll RF: Early surfactant administration with brief ventilation vs. selective surfactant and continued mechanical ventilation for preterm infants with or at risk for respiratory distress syndrome. Cochrane Database Syst Rev 2007; 4:CD003063.

7 Whitsett JA, Hull WM, Ohning B, Ross G, Weaver TE: Immunologic identification of a pulmonary surfactant-associated protein of molecular weight $=6000$ daltons. Pediatr Res 1986;20:744-749.

$>$ Whitsett JA, Ohning BL, Ross G, Meuth J, Weaver T, Holm BA, Shapiro DL, Notter RH: Hydrophobic surfactant-associated protein in whole lung surfactant and its importance for biophysical activity in lung surfactant extracts used for replacement therapy. Pediatr Res 1986;20:460-467.

9 Notter RH, Shapiro DL, Ohning B, Whitsett JA: Biophysical activity of synthetic phospholipids combined with purified lung surfactant 6000 dalton apoprotein. Chem Phys Lipids 1987;44:1-17. 
$>10$ Rider ED, Ikegami M, Whitsett JA, Hull W, Absolom D, Jobe AH: Treatment responses to surfactants containing natural surfactant proteins in preterm rabbits. Am Rev Respir Dis 1993;147:669-676.

-11 Whitsett JA, Wert SE, Weaver TE: Alveolar surfactant homeostasis and the pathogenesis of pulmonary disease. Annu Rev Med 2010; 61:105-119.

12 Whitsett JA, Weaver TE: Hydrophobic surfactant proteins in lung function and disease. N Engl J Med 2002;347:2141-2148.

13 McCormack FX, Whitsett JA: The pulmonary collectins, SP-A and SP-D, orchestrate innate immunity in the lung. J Clin Invest 2002;109: 707-712.

14 Ariki S, Nishitani C, Kuroki Y: Diverse functions of pulmonary collectins in host defense of the lung. J Biomed Biotechnol 2012;2012: 532071.

15 Perez-Gil J, Weaver TE: Pulmonary surfactant pathophysiology: current models and open questions. Physiology 2010;25:132-141.

16 Curstedt T, Calkovska A, Johansson J: New generation synthetic surfactants. Neonatology 2013;103:327-330.

17 Kurland G, Deterding RR, Hagood JS, Young LR, Brody, AS, Castile RG, Dell S, et al; American Thoracic Society Committee on Childhood Interstitial Lung Disease and the Child Research Network: An official American Thoracic Society clinical practice guideline: classification, evaluation, and management of childhood interstitial lung disease in infancy. Am J Respir Crit Care Med 2013;188:376-394.

18 Wert SE, Whitsett JA, Nogee LM: Genetic disorders of surfactant dysfunction. Pediatr Dev Pathol 2009;12:253-274.

19 Nogee LM, Garnier G, Dietz HC, Singer L, Murphy AM, deMello DE, Colten HR: A mutation in the surfactant protein $B$ gene responsible for fatal neonatal respiratory disease in multiple kindreds. J Clin Invest 1994;93: 1860-1863.

20 Clark JC, Wert SE, Bachurski CJ, Stahlman MT, Stripp BR, Weaver TE, Whitsett JA: Targeted disruption of the surfactant protein $\mathrm{B}$ gene disrupts surfactant homeostasis, causing respiratory failure in newborn mice. Proc Natl Acad Sci USA 1995;92:7794-7798.

-21 Melton KR, Nesslein LL, Ikegami M, Tichelaar JW, Clark JC, Whitsett JA, Weaver TE: SP-B deficiency causes respiratory failure in adult mice. Am J Physiol Lung Cell Mol Physiol 2003;285:L543-L549.

$\checkmark 22$ Nogee LM, Wert SE, Proffit SA, Hull WM, Whitsett JA: Allelic heterogeneity in hereditary surfactant protein B (SP-B) deficiency. Am J Respir Crit Care Med 2000;161:973981.

-23 Shulenin S, Nogee LM, Annilo T, Wert SE, Whitsett JA, Dean M: ABCA3 gene mutations in newborns with fatal surfactant deficiency. N Engl J Med 2004;350:1296-1303.

24 Hayes D Jr, Lloyd EA, Fitch JA, Bush A: ABCA3 transporter deficiency. Am J Respir Crit Care Med 2012;186:807.
25 Bohinski RJ, Di Lauro R, Whitsett JA: The lung-specific surfactant protein $B$ gene promoter is a target for thyroid transcription factor 1 and hepatocyte nuclear factor 3 , indicating common factors for organ-specific gene expression along the foregut axis. Mol Cell Biol 1994;14:5671-5681.

26 Kimura S, Hara Y, Pineau T, Fernandez-Salguero P, Fox CH, Ward JM, Gonzalez FJ: The T/ebp null mouse: thyroid-specific enhancerbinding protein is essential for the organogenesis of the thyroid, lung, ventral forebrain, and pituitary. Genes Dev 1996;10:60-69.

27 DeFelice M, Silberschmidt D, DiLauro R, Xu Y, Wert SE, Weaver TE, Bachurski CJ, Clark JC, Whitsett JA: TTF-1 phosphorylation is required for peripheral lung morphogenesis, perinatal survival, and tissue- specific gene expression. J Biol Chem 2003;278:35574-35583.

$\checkmark 28$ Guillot L, Carre A, Szinnai G, Castanet M, Tron E, Jaubert F, Broutin I, Counil F, Feldmann D, Clement A, Polak M, Epaud R: NKX2-1 mutations leading to surfactant protein promoter dysregulation cause interstitial lung disease in 'Brain-Lung-Thyroid Syndrome'. Hum Mutat 2010;31:E1146-E1162.

29 Hamvas A, Deterding RR, Wert SE, White FV, Dishop MK, Alfano DN, Halbower AC, et al: Heterogeneous pulmonary phenotypes associated with mutations in the thyroid transcription factor gene NKX2-1. Chest 2013; 144:794-804

30 Young LR, Deutsch GH, Bokulic RE, Brody AS, Nogee LM: A mutation in TTF1/NKX2.1 is associated with familial neuroendocrine cell hyperplasia of infancy. Chest 2013;144: 1199-1206.

-31 Alameh J, Bachiri A, Devisme L, Truffert P, Rakza TR, Riou Y, Manouvrier S, Lequien P, Storme L: Alveolar capillary dysplasia: a cause of persistent pulmonary hypertension of the newborn. Eur J Pediatr 2002;161:262-266.

32 Kalinichenko VV, Lim L, Stolz DB, Shin B, Rausa FM, Clark J, Whitsett JA, Watkins SC, Costa RH: Defects in pulmonary vasculature and perinatal lung hemorrhage in mice heterozygous null for the Forkhead Box f1 transcription factor. Dev Biol 2001;235:489-506.

-33 Stankiewicz P, Sen P, Bhatt SS, Storer M, Xia $\mathrm{Z}$, Beijani BA, Ou Z, et al: Genomic and genic deletions of the FOX gene cluster on 16q24.1 and inactivating mutations of FOXF1 cause alveolar capillary dysplasia and other malformations. Am J Hum Genet 2009;84:780-791.

-34 Kalin TV, Meliton L, Meliton AY, Zhu X, Whitsett JA, Kalinichenko VV: Pulmonary mastocytosis and enhanced lung inflammation in mice heterozygous null for the FOXF1 gene. Am J Respir Cell Mol Biol 2008;39:390-399.

35 Vorbroker DK, Voorhout WF, Weaver TE, Whitsett JA: Posttranslational processing of surfactant protein C in rat type II cells. Am J Physiol 1995;269:L727-L733.

36 Glasser SW, Detmer EA, Ikegami M, Na CL, Stahlman MT, Whitsett JA: Pneumonitis and emphysema in sp-C gene targeted mice. J Biol Chem 2003;278:14291-14298.
37 Glasser SW, Senft AP, Whitsett JA, Maxfield MD, Ross GF, Richardson TR, Prows DR, Xu Y, Korfhagen TR: Macrophage dysfunction and susceptibility to pulmonary Pseudomonas aeruginosa infection in surfactant protein C-deficient mice. J Immunol 2008;181:621628

38 Glasser SW, Maxfield MD, Ruetschilling TL, Akinbi HT, Baatz JE, Kitzmiller JA, Page K, Xu Y, Bao EL, Korfhagen TR: Persistence of LPS-induced lung inflammation in surfactant protein-C-deficient mice. Am J Respir Cell Mol Biol 2013;49:845-854

39 Willander H, Askarieh G, Landreh M, Westermark P, Nordling K, Keranen H, Hermansson E, et al: High-resolution structure of a BRICHOS domain and its implications for anti-amyloid chaperone activity on lung surfactant protein C. Proc Natl Acad Sci USA 2012;109:2325-2329.

40 Nogee LM, Dunbar AE, 3rd, Wert SE, Askin F, Hamvas A, Whitsett JA: A mutation in the surfactant protein $\mathrm{C}$ gene associated with familial interstitial lung disease. N Engl J Med 2001;344:573-579.

41 Bridges JP, Xu, Y, Na, CL, Wong HR, Weaver TE: Adaptation and increased susceptibility to infection associated with constitutive expression of misfolded SP-C. J Cell Biol 2006; 172:395-407.

42 Woischnik M, Sparr C, Kern S, Thurm T, Hector A, Hartl D, Liebisch G, et al: A nonBRICHOS surfactant protein $\mathrm{c}$ mutation disrupts epithelial cell function and intercellular signaling. BMC Cell Biol 2010;11:88.

43 Thomas AQ, Lane K, Phillips J 3rd, Prince M, Markin C, Speer M, Schwartz DA, et al: Heterozygosity for a surfactant protein $\mathrm{C}$ gene mutation associated with usual interstitial pneumonitis and cellular nonspecific interstitial pneumonitis in one kindred. Am J Respir Crit Care Med 2002;165:1322-1328.

44 Lawson WE, Grant SW, Ambrosini V, Ambrosini V, Womble KE, Dawson EP, Lane KB, et al: Genetic mutations in surfactant protein $\mathrm{C}$ are a rare cause of sporadic cases of IPF. Thorax 2004;59:977-980.

45 Kingma PS, Whitsett JA: In defense of the lung: surfactant protein A and surfactant protein D. Curr Opin Pharmacol 2006;6:277283.

46 Korfhagen TR, Bruno MD, Ross GF, Huelsman KM, Ikegami M, Jobe AH, Wert SE, et al: Altered surfactant function and structure in SP-A gene targeted mice. Proc Natl Acad Sci USA 1996;93:9594-9599.

47 Garcia CK: Idiopathic pulmonary fibrosis: update on genetic discoveries. Proc Am Thorac Soc 2011;8:158-162.

48 Maitra M, Dey M, Yuan WC, Nathanielsz PW, Garcia CK: Lung fibrosis-associated surfactant protein $\mathrm{A} 1$ and $\mathrm{C}$ variants induce latent transforming growth factor betal secretion in lung epithelial cells. J Biol Chem 2013; 288:27159-27171. 
49 Iniesta P, Gonzalez-Quevedo R, Moran A, Garcia-Aranda C, de Juan C, Sanchez-Permaute A, Torres A, Diaz-Rubio E, Balibrea JL, Benito M: Relationship between $3 p$ deletions and telomerase activity in non-small-cell lung cancer: prognostic implications. Br J Cancer 2004;90:1983-1988.

-50 Devine MS, Garcia CK: Genetic interstitial lung disease. Clin Chest Med 2012;33:95-110.

-51 Brennan P, Hainaut P, Boffetta P: Genetics of lung-cancer susceptibility. Lancet Oncol 2011;12:399-408.

52 Todd DA, Marsh MJ, George A, Henderson NG, Barr H, Sebastian S, Clark GT, Koster G, Clark HW, Postle AD: Surfactant phospholipids, surfactant proteins, and inflammatory markers during acute lung injury in children. Pediatr Crit Care Med 2010;11:82-91.

53 Ichiyasu H, Ichikado K, Yamashita A, Iyonaga K, Sakamoto O, Suga M, Kohrogi H: Pneumocyte biomarkers KL-6 and surfactant protein $\mathrm{D}$ reflect the distinct findings of high-resolution computed tomography in nonspecific interstitial pneumonia. Respiration 2012;83: 190-197.

54 Zhang Y, Kaminski N: Biomarkers in idiopathic pulmonary fibrosis. Curr Opin Pulm Med 2012;18:441-446.

55 Ishikawa T, Kubota T, Abe H, Hirose K, Nagashima A, Togashi T, Seki K, Honma T, Yoshida T, Kamimura T: Surfactant protein-D is more useful than Krebs von den Lungen 6 as a marker for the early diagnosis of interstitial pneumonitis during pegylated interferon treatment for chronic hepatitis C. Hepatogastroenterology 2012;59:2260-2263.

56 Bowler RP: Surfactant protein D as a biomarker for chronic obstructive pulmonary disease. COPD 2012;9:651-653.
57 Honda Y, Kuroki Y, Matsuura E, Nagae H, Takahashi H, Akino T, Abe S: Pulmonary surfactant protein $\mathrm{D}$ in sera and bronchoalveolar lavage fluids. Am J Respir Crit Care Med 1995; 152:1860-1866.

58 Trapnell BC, Whitsett JA, Nakata K: Pulmonary alveolar proteinosis. N Engl J Med 2003; 349:2527-2539.

59 Kitamura T, Tanaka N, Watanabe J, Uchida, Kanegaski S, Yamada Y, Nakata K: Idiopathic pulmonary alveolar proteinosis as an autoimmune disease with neutralizing antibody against granulocyte/macrophage colonystimulating factor. J Exp Med 1999;190:875880.

60 Suzuki T, Maranda B, Sakagami T, Catellier P, Couture CY, Carey BC, Chalk C, Trapnell BC: Hereditary pulmonary alveolar proteinosis caused by recessive CSF2RB mutations. Eur Respir J 2011;37:201-204.

-61 Suzuki T, Sakagami T, Rubin BK, Nogee LM, Wood RE, Zimmerman SL, Smolarek T, et al: Familial pulmonary alveolar proteinosis caused by mutations in CSF2RA. J Exp Med 2008;205:2703-2710.

62 Tanaka T, Motoi N, Tsuchihashi Y, Tazawa R, Kaneko C, Nei T, Yamamoto T, et al: Adultonset hereditary pulmonary alveolar proteinosis caused by a single-base deletion in CSF2RB. J Med Genet 2011;48:205-209.

63 Uchida K, Nakata K, Carey B, Chalk C, Suzuki T, Sakagami T, Koch DE, et al: Standardized serum GM-CSF autoantibody testing for the routine clinical diagnosis of autoimmune pulmonary alveolar proteinosis. J Immunol Methods 2014;402:57-70.

64 Suzuki T, Mayhew C, Sallese A, Chalk C, Carey BC, Malik P, Wood RE, Trapnell BC: Use of induced pluripotent stem cells to recapitulate pulmonary alveolar proteinosis pathogenesis. Am J Respir Crit Care Med 2014;189: 183-193.
65 Luisetti M, Kadija Z, Mariani F, Rodi G, Campo I, Trapnell BC: Therapy options in pulmonary alveolar proteinosis. Ther Adv Respir Dis 2010;4:239-248.

66 Suzuki T, Sakagami T, Young LR, Carey BC, Wood RE, Luisetti M, Wert SE, et al: Hereditary pulmonary alveolar proteinosis: pathogenesis, presentation, diagnosis, and therapy. Am J Respir Crit Care Med 2010;182:12921304.

67 Sarin VK, Gupta S, Leung TK, Taylor VE, Ohning BL, Whitsett JA, Fox JL: Biophysical and biological activity of a synthetic $8.7-\mathrm{kDa}$ hydrophobic pulmonary surfactant protein SPB. Proc Natl Acad Sci USA 1990;87:26332637.

68 Baatz JE, Sarin V, Absolom DR, Baxter C, Whitsett JA: Effects of surfactant-associated protein SP-B synthetic analogs on the structure and surface activity of model membrane bilayers. Chem Phys Lipids 1991;60:163-178.

69 Cochrane CG, Revak SD, Merritt TA, Heldt GP, Hallman M, Cunningham MD, Easa D, Pramanik A, Edwards DK, Alberts MS: The efficacy and safety of KL4-surfactant in preterm infants with respiratory distress syndrome. Am J Respir Crit Care Med 1996;153: 404-410.

70 Cochrane CG: Surfactant protein B and mimic peptides in the function of pulmonary surfactant. FEBS Lett 1998;430:424; disc 425.

71 Speer CP, Sweet DG, Halliday HL: Surfactant therapy: past, present and future. Early Hum Dev 2013;89:S22-S24.

72 Seehase M, Collins JJ, Kuypers E, Jellema RK, Ophelders DR, Ospina OL, Perez-Gil J, Bianco F, Garzia R, Razzetti R, Kramer BW: New surfactant with SP-B and $\mathrm{C}$ analogs gives survival benefit after inactivation in preterm lambs. PLoS One 2012;7:e47631. 